\title{
Detection of pea seed-borne mosaic virus virion and pinwheel inclusion body proteins in leaf and seed tissues of pea (Pisum sativum L) by immunogold labelling
}

\author{
D Wang *, RD Woods, AG Swaby, AJ Cockbain \\ AFRC Institute of Arable Crops Research, Rothamsted Experimental Station, Harpenden, Herts, AL5 2JQ, UK
}

(Received 30 January 1990; accepted 11 February 1991)

\begin{abstract}
Summary - An immunogold labelling procedure was developed to detect pea seed-borne mosaic virus (PSbMV) virion and pinwheel inclusion body proteins in leaf and seed tissues of pea and to study the cytology of PSbMV infection in this host. Ultrathin sections were treated with immunoglobulin prepared against either PSbMV particles or PSbMV pinwheel inclusion bodies. The sections were then probed with gold-labelled goat antirabbit immunoglobulin. With immunoglobulin against PSBMV particles, virus particles, but not pinwheel and crystalline inclusions, were specifically labelled. With immunoglobulin against pinwheel inclusion bodies, pinwheel inclusion bodies (bundles and scrolls) were specifically labelled, but neither PSbMV particles nor its crystalline inclusion bodies were labelled, showing that the crystalline inclusion body protein was unrelated to either virus coat protein or the pinwheel inclusion protein. When cotyledon and plumule sections cut from fixed seed tissues were treated with the 2 types of immunoglobulin, only PSbMV particle bundles were labelled, indicating that in seed tissues, the pinwheel inclusion was structurally different from that in leaf tissues.
\end{abstract}

immunogold labelling / PSbMV / viral particle / inclusion body

Résumé - Détection du virion de la mosaïque du pois et des protéines d'inclusions cytoplasmiques dans les feuilles et les grains de pois (Pisum sativum L) par immuno-marquage à l'or. Un immuno-marquage à l'or colloídal a été optimisé pour la détection in situ du virus et des inclusions cytoplasmiques (CCI) dans les tissus foliaires et les grains de pois infectés par le pea seed-borne mosaic virus (PSbMV) (figs 1,2, 3, tableau I). Des coupes ultrafines de tissu ont été incubées en présence d'anticorps de lapin préparés soit contre le virus, soit contre les $\mathrm{CCl}$, puis ont été traitées par des anticorps de chèvre anti-lapin couplés à des billes d'or colloïdal. Avec le sérum anti virus, seules les particles virales ont été décorées, les $\mathrm{CCl}$ et les inclusions cristallines ne présentant aucun marquage (fig 4). Avec le sérum anti- $\mathrm{CCl}$, les inclusions cytoplasmiques cylindriques ont été marquées alors que le virus et les inclusions cristallines n'ont pas été reconnus (figs 5, 6). Ces résultats montrent que les inclusions cristallines ne sont sérologiquement reliées ni au virus ni aux $\mathrm{CCl}$. Quand des coupes de cotylédon ou de gemmule réalisées à partir de graines préalablement fixées ont été traitées avec ces 2 anticorps, seuls les amas de particules virales ont été décorés indiquant une différence de structure entre les $\mathrm{CCl}$ formées dans les feuilles et celles formées dans les graines (fig 7).

marquage immunologique à l'or / PSbMV / virion / inclusion

\section{INTRODUCTION}

Members of the potyvirus group of plant virus induce the formation of several types of inclusion body during infection (Edwardson, 1974; Christie and Edwardson, 1977; Hollings and Brunt, 1981; Dougherty and Carrington, 1988). With pea seedborne mosaic virus (PSbMV) in pea (Pisum sati- vum L) 2 distinctive types of cytoplasmic inclusion body, the pinwheel type and the crystalline type, have been described (Inouye, 1971; Hampton et al, 1973; Miličic and Plavsic, 1978). An antiserum to the pinwheel inclusion body protein of PSbMV has been prepared and used in enzymelinked immunosorbent assay (ELISA) to detect the protein during PSbMV infection (Alconero et

" Correspondence and reprints 
al, 1986). However, the serological relationship between the pinwheel and the crystalline inclusion bodies remains unknown. Here, we report the development of an immunogold labelling procedure using antisera to PSbMV particles and pinwheel inclusion bodies, and its application to the study of the cytology of PSbMV infection. An important property of PSbMV is its high rate of seed transmission in some pea cultivars (Musil, 1966; Inouye, 1967; Stevenson and Hagedorn, 1969; Khetarpal and Maury, 1987). Our attempts to understand the mechanism of PSbMV seed transmission involve the study of the movement of PSbMV during host embryogenesis, and one of the essential requirements for this is a sensitive and specific cytological detection technique. This led us to test the suitability of immunogold labelling for the detection of PSbMV in leaf and seed tissues.

\section{MATERIALS AND METHODS}

\section{Virus, host plants and virus infected seeds}

An isolate of PSbMV from an infected seed of pea cV Waverex was propagated in pea plants (cv Vedette) in a glasshouse at $20-22{ }^{\circ} \mathrm{C}$ with a $14 \mathrm{~h}$ light period. Five wk after mechanical inoculation, tissue pieces were taken from systemically-infected leaves for tissue preparation. PSbMV infected seeds were harvested from diseased plants (cv Vedette) grown in a glasshouse.

\section{Chemicals, antisera and the immunogold reagent}

LR white (medium grade, London Resin Co Ltd) was used as the embedding medium for leaf tissues and agar resin 100 (Agar Scientific Ltd) was used as the embedding medium for seed parts. An antiserum to PSbMV particles was raised and immunoglobulin $(1 \mathrm{mg} / \mathrm{ml})$ was purified from it by ammonium sulphate precipitation. A sample of purified anti-PSbMV pinwheel inclusion body protein immunoglobulin $(1 \mathrm{mg} /$ mi) was obtained from R Alconero (Germplasm Resources Unit, Northeast Regional Plant Introduction Station, USA). Goat antirabbit immunoglobulin (Sigma) was coupled to $15-20 \mathrm{~nm}$ colloidal gold according to Lin and Langenberg (1983).

\section{Antiserum specificity}

To test the specificity of the antiserum against PSbMV particles, purified PSbMV particles were absorbed onto copper grids, coated with diluted immunoglobulin prepared from the crude antiserum against PSbMV particles and immunogold-labelled essentially as described by Van Lent and Verduin (1985) except that goat antirabbit immunoglobulin-gold conjugate was used rather then protein A-gold conjugate.

The pinwheel inclusion bodies induced by the PSbMV isolate in systemically-infected pea plants (cV Vedette) were purified according to Mowat et al (1989) and used to test the specificity of the anti-pinwheel inclusion serum (Alconero et al, 1986). Purified pinwheel inclusion bodies were prepared for SDSpolyacrylamide gel electrophoresis according to Laemmli (1970). After electrophoresis, the protein samples were electroblotted onto nitrocellulose membrane strips. The strips were then incubated in a series of antibody solutions which had been preabsorbed with different amounts of purified pinwheel inclusion body protein. After antigen-antibody reaction, the western blot procedure was completed according to White et al (1987).

The specificity of the 2 antisera was further tested by incubating tissue sections in a series of preabsorbed antibody solutions followed by gold-labelling. Thin sections were cut from fixed infected leaf and cotyledon materials as described below. The intensity of gold-labelling by each antibody treatment was photographically recorded under electron microscope and compared. Specific recognition of PSbMV virion and pinwheel inclusion body protein by the above 2 antisera was also demonstrated by western blot analyses of crude protein extracts of infested leaf tissues of pea. The extracts were prepared according to Sherwood (1987), the western blot procedure was completed as above except that the concentrations of the 2 antibody solutions used were both at $1 \mathrm{ng} / \mathrm{ml}$ and nonabsorbed.

\section{Tissue preparation}

Leaf pieces $(3 \times 1 \mathrm{~mm})$ from healthy and infected plants were fixed in $2 \%$ glutaraldehyde overnight at $4^{\circ} \mathrm{C}$ and postfixed in $1 \%$ osmium tetroxide for $4 \mathrm{~h}$ at room temperature. After rinsing in distilled water, they were dehydrated in an ascending series of ethanol solutions $(50,70,90$ and $100 \%, 15 \mathrm{~min}$ in each). After passing through a series of ethanol/methylacetate mixtures ( $v / v, 50 / 50,25 / 75,0 / 100,15 \mathrm{~min}$ each), they were treated with different concentrations of LR white resin in methylacetate, $20 \%$ for $1 \mathrm{~h}, 50 \%$ for $2 \mathrm{~h}, 80 \%$ overnight and $100 \%$ for $4 \mathrm{~h}$, all at room temperature. They were then transferred to clean plastic bags $(4 \times 2$ $\mathrm{cm}$ ) with a small volume of fresh LR white resin in each bag. After excluding all air bubbles, the plastic bags were sealed and placed under ultraviolet light at $-20^{\circ} \mathrm{C}$ for $48 \mathrm{~h}$ to polymerize the resin.

Small tissue pieces $(3 \times 1 \mathrm{~mm})$ from the cotyledons and plumules of healthy and infected seeds were fixed in $2.5 \%$ glutaraldehyde for $5 \mathrm{~h}$ and postfixed in $1 \%$ osmium tetroxide avernight. After dehydration in an ascending series of acetone solutions $(30,50,70,90$, 
and $100 \%, 1 \mathrm{~h}$ in each), acetone in the tissues was replaced by propylene oxide. Tissue pieces were then passed through ascending concentrations of Agar 100 resin in propylene oxide ( $25 \%$ for $1 \mathrm{~h}, 50 \%$ for $1 \mathrm{~h}$, $75 \%$ for $1 \mathrm{~h}$ and $90 \%$ overnight) at room temperature and finally embedded in pure fresh Agar 100 resin at $70^{\circ} \mathrm{C}$ for $48 \mathrm{~h}$.

\section{Immunocytochemical staining}

Thin sections were cut with a Reichert Ultracut Ultramicrotome, and picked up on Formvar-coated nickel grids. These grids were placed face down on drops of saturated sodium metaperiodate solution to restore protein antigenicity on the osmicated tissue sections (Bendayan and Zollinger, 1983). After brief washing with distilled water, they were floated on drops of $1 \%$ bovine serum albumin (BSA) in $0.02 \mathrm{M}$ Tris- $\mathrm{HCl}$ buffer containing $0.5 \mathrm{M} \mathrm{NaCl}$ (BSA-TBS), pH 7.5 for $15 \mathrm{~min}$ at room temperature to block non-specific binding sites. The grids were then treated with different antibody solutions under different time and temperature conditions. A stringent washing procedure of 80 drops of TBS for each grid followed each antibody treatment. The grids were further incubated with the immunogold reagent diluted 1:10 in BSA-TBS at room temperature for different times. After another stringent wash, first with TBS then with distilled water, the grids were stained for $15 \mathrm{~min}$ with water saturated uranyl acetate with or without lead citrate staining for $5 \mathrm{~min}$. As a control, thin sections cut from healthy leaf and seed tissues were treated as above. All grids were examined in a Philips 201 electron microscope.

\section{RESULTS}

\section{Confirmation of antiserum specificity}

In the gold-labelled antibody decoration tests, antiserum against PSbMV particles specifically reacted with the antigenic epitopes of PSbMV particles (fig 1a). In parallel control tests, PSbMV particles which did not receive antibody-coating treatment did not show any gold labelling. In the western blot analysis for PSbMV pinwheel inclusion protein, nitrocellulose strips which were incubated in preabsorbed antibody solution showed much decreased signals, whereas the signal produced in the nitrocellulose membrane incubated in the unabsorbed antibody solution was much stronger (fig 1b). This indicated that the purified inclusion body protein added to the antibody solution specifically react with the antibody, reduced the effective concentration of the antibody and caused the signal reduction in subsequent western blot tests.

In the labelling experiments of infected leaf and cotyledon sections, preabsorption of the 2 primary antibody solutions with purified pinwheel inclusion body protein and purified virus particle protein respectively led to a consistent reduction of the labelling intensity of viral structures (fig 2). Treatment of the 2 antibody solutions (both at 1 $\mathrm{mg} / \mathrm{ml}$ ) with $0.9 \mathrm{mg}$ purified antigen proteins completely abolished the labelling of viral structures in the sections. These results confirmed the labelling specificity of the 2 antisera for their respective antigens in fixed configuration and cellular environment.

In Western blot analyses of crude protein extracts of infected pea leaf tissues, the 2 antisera were shown to specifically recognize single protein bands equivalent in size to virus coat protein and pinwheel inclusion protein (data not shown). This finding, together with the results from above experiments, demonstrated unambiguously that the 2 antisera used in this study were specific for their respective antigens.

\section{Optimization of the immunogold labelling procedure}

Altering the conditions of the 3 principal steps of the immunogold labelling procedure, namely, sodium metaperiodate incubation, antibody treatment and gold labelling, affected the final labelling results of the procedures tested, procedure 4 consistently gave the best results (table I, fig 3). Hence, in subsequent experiments, all leaf sections were processed by this procedure. Because the ultrastructural preservation in the experiments was adequate, some leaf sections were labelled but not stained with lead. In these sections the specific labelling of virus structures was much easier to identify.

\section{Leaf sections treated with anti-PSbMV particle immunoglobulin}

PSbMV particles in the cytoplasm were specifically labelled, but pinwheel inclusion bodies (bundles and scrolls) were not. However, there was specific labelling in the spaces adjacent to some bundles and scrolls where the association of PSbMV particles was evident. There was also some labelling in the spaces among bundles 


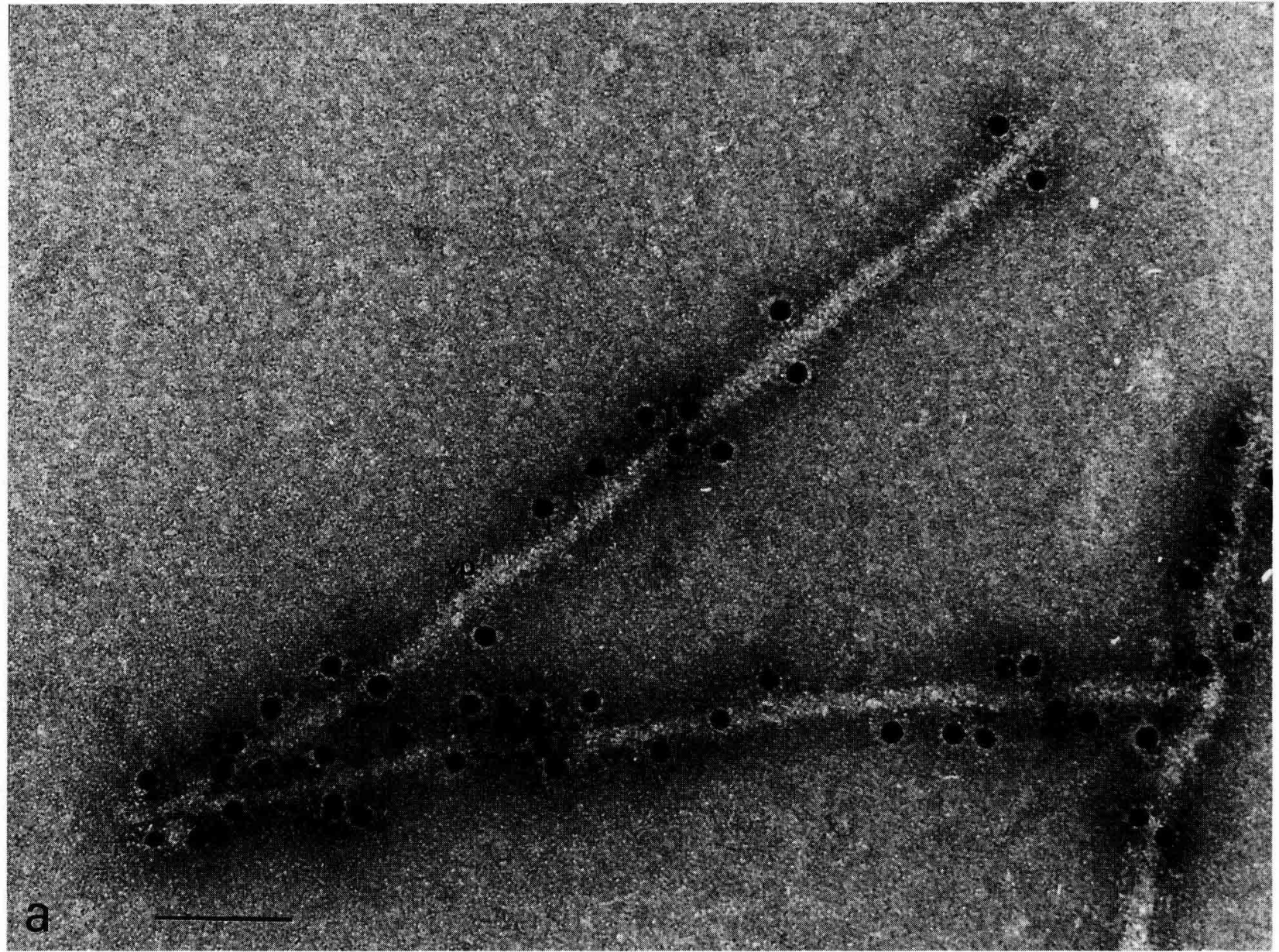

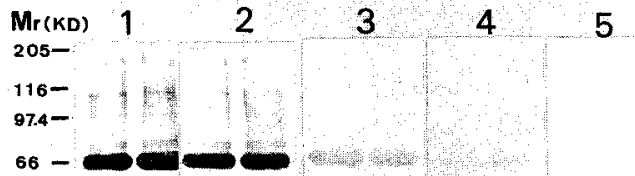

and scrolls where PSbMV particles were not visible, possibly due to the presence of viral coat proteins in these areas. Crystalline inclusion bodies were not labelled (fig 4).

\section{Leaf sections treated with anti-PSbMV pinwheel inclusion body immunoglobulin}

Bundles and scrolls were specifically labelled. But there was no labelling in the spaces among scrolls or between bundles and scrolls (fig 5).
Fig 1. a) Specific coating of PSbMV particles (VP) by antiPSbMV particle immunoglobulin and immunogold detection of the antigen-antibody complex. Bar: $100 \mathrm{~nm}$; b) Western blotting analyses of anti-PSbMV pinwheel inclusion body protein antiserum. Nitrocellulose membrane strips were incubated in unabsorbed and absorbed antibody solutions. 1) Unabsorbed antibody solution (1 mg/ml); 2) antibody solution ( $1 \mathrm{mg} / \mathrm{ml}$ ) absorbed with $0.5 \mathrm{mg}$ purified PSBMV pinwheel inclusion body protein; 3 ) antibody solution $(1 \mathrm{mg} / \mathrm{ml})$ absorbed with $0.9 \mathrm{mg}$ purified PSbMV pinwheel inclusion body protein; 4) antibody solution (1 $\mathrm{mg} / \mathrm{ml})$ absorbed with $1 \mathrm{mg}$ purified PSBMV pinwheel inclusion body protein; 5) control solution without anti-PSBMV pinwheel inclusion body antibody.

PSbMV particles or crystalline inclusion bodies in these sections were not labelled.

\section{Leaf sections treated with a mixture of the 2 types of immunoglobulin}

PSbMV particles scattered in some areas adjacent to scrolls and scrolls themselves were specifically labelled, but in many more infected cells, only bundle and scroll labelling was observed. Crystalline inclusion bodies were again un- 

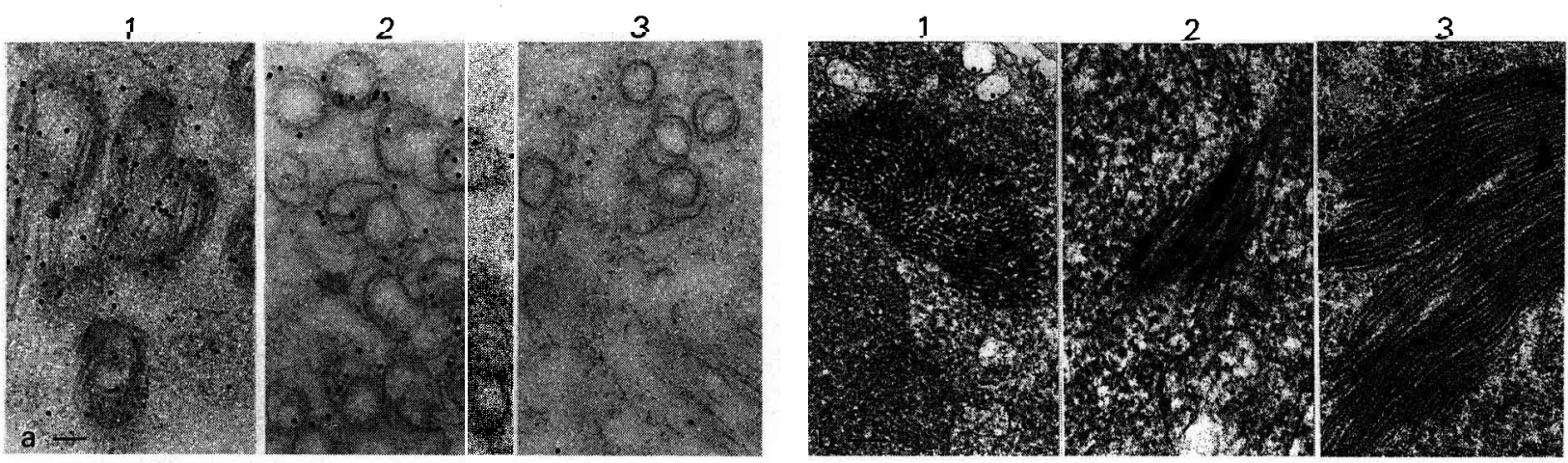

Fig 2. Demonstration of the specificity of the antisera for their respective antigens in tissue sections. Sections were incubated in unabsorbed and absorbed antibody solutions followed by gold labelling. 1) Unabsorbed antibody solution ( $1 \mathrm{mg} / \mathrm{ml})$; 2) antibody solution (1 mg/ml) absorbed with $0.5 \mathrm{mg}$ protein; 3) antibody solution ( $1 \mathrm{mg} / \mathrm{ml})$ absorbed with $0.9 \mathrm{mg}$ protein; a) anti-PSbMV pinwheel inclusion body protein antiserum; b), anti-PSbMV particle antiserum. Bars: $100 \mathrm{~nm}$.

labelled whereas adjacent scrolls were intensively labelled (fig 6).

\section{Cotyledon and plumule sections treated with a mixture of the 2 types of immunoglobulin}

When procedure 4 was used for labelling PSbMV structures in cotyledon and plumule sections, a
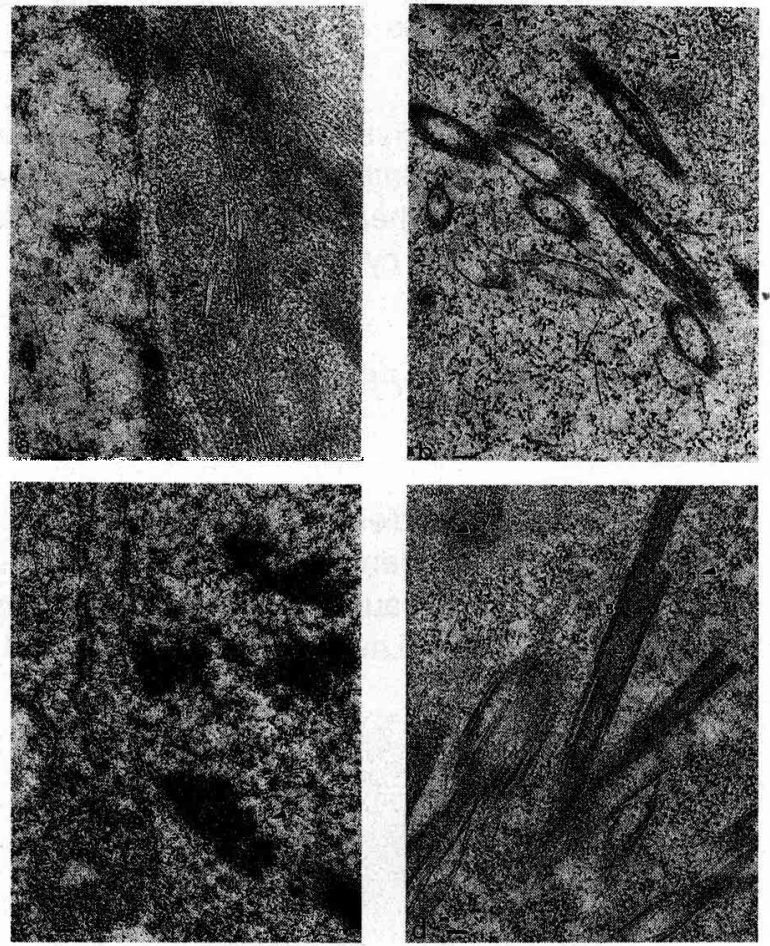

Fig 3. a,b) Healthy and infected leaf tissues immunocytologically stained by procedure 2 . Non-specific staining (arrows) present in high concentration in chloroplast (Ch), cytoplasm (Cy) and nucleus (N). Gold staining present over PSbMV pinwheel inclusion bodies (scrolls, S). Bar: $100 \mathrm{~nm}$; c,d) Healthy and infected leaf tissues immunocytologically stained by procedure 4. Non-specific staining (arrows) present in low concentration in cytoplasm (Cy) and nucleus (N). Specific labelling present over PSBMV pinwheel inclusion bodies (bundles, B). Bars: $100 \mathrm{~nm}$. decrease in sensitivity was encountered. There was no appreciable amount of specific labelling of either particles or pinwheel inclusion bodies. Consequently, procedure 3 was used for these sections. Specific labelling was obtained on PSbMV particle bundles (fig 7), but there was still no positive labelling on pinwheel inclusion bodies.
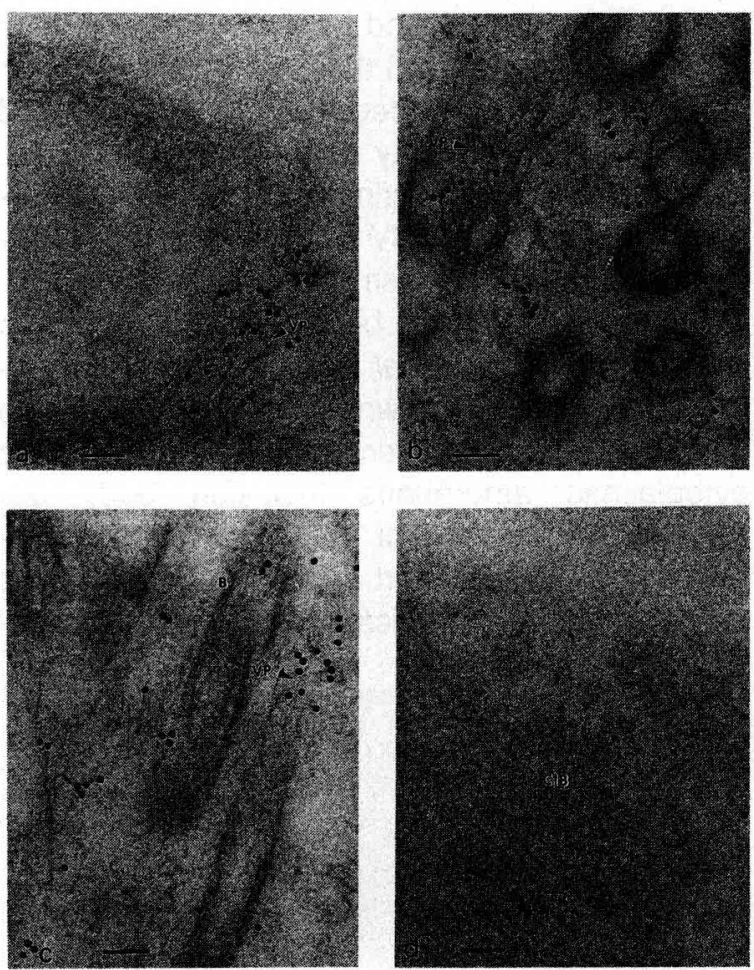

Fig 4. Infected leaf tissues treated with anti-PSbMV particle immunoglobulin. Virus particles (VP, arrows) specifically labelled. No lead citrate staining of sections. a) Virus particles in cytoplasm; b) virus particles associated with scroll.Scrolls unlabelled. Spaces among scrolls labelled; c) virus particles associated with bundle. Bundles unlabelled. Spaces among bundles labelled; d) crystalline inclusion body (ClB) unlabelled. Bars: $100 \mathrm{~nm}$. 

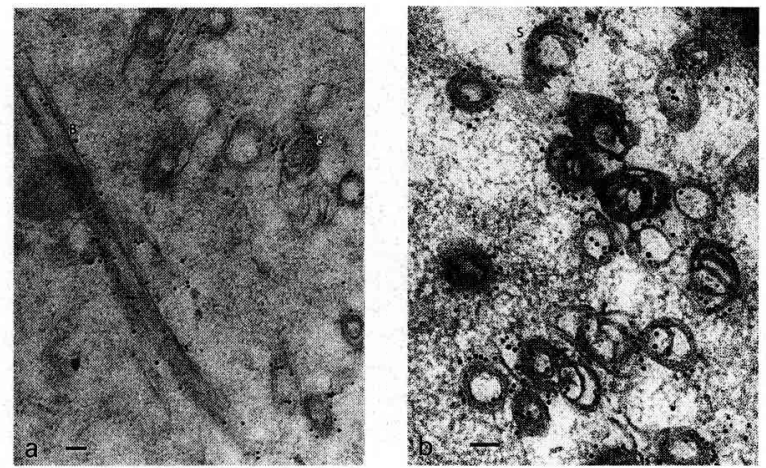

Fig 5. Infected leaf tissues treated with anti-PSbMV pinwhee inclusion body immunoglobulin. a) Bundles and scrolls specifically labelled. No lead citrate staining of sections; b) scrolls specifically labelled. Spaces among scrolls unlabelled. Bars: $100 \mathrm{~nm}$.

\section{DISCUSSION}

\section{PSBMV particles, pinwheel and crystalline inclusion bodies}

All potyviruses so far studied induce the formation of pinwheel inclusion bodies in the cytoplasm of infected cells (Dougherty and Carrington, 1988). By contrast, crystalline inclusion bodies have been found in only a few potyvirus induced infections, and they are usually present in the nuclei of the infected cells (Hollings and Brunt, 1981; Dougherty and Carrington, 1988). However, in our experiments, crystalline inclusion bodies of PSbMV were consistently observed in the cytoplasm of the infected cells. Similar findings have been reported by other workers (Hampton et al, 1973; Miličic and Plavsic, 1978). It is not known whether this crystalline structure in PSbMV infection is equivalent to the cytoplasmic amorphous inclusion body described for infections of tobacco plants by pepper mottle virus (Hiebert et al, 1984). Our results here have clearly indicated that PSbMV parti-

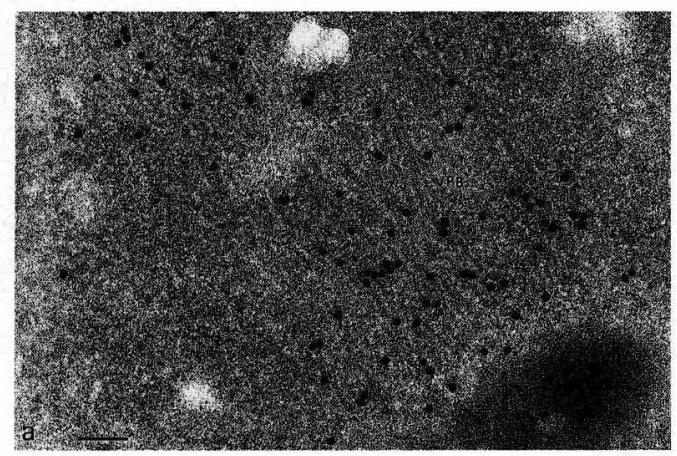

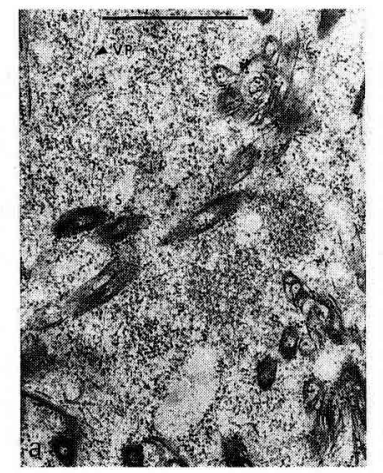
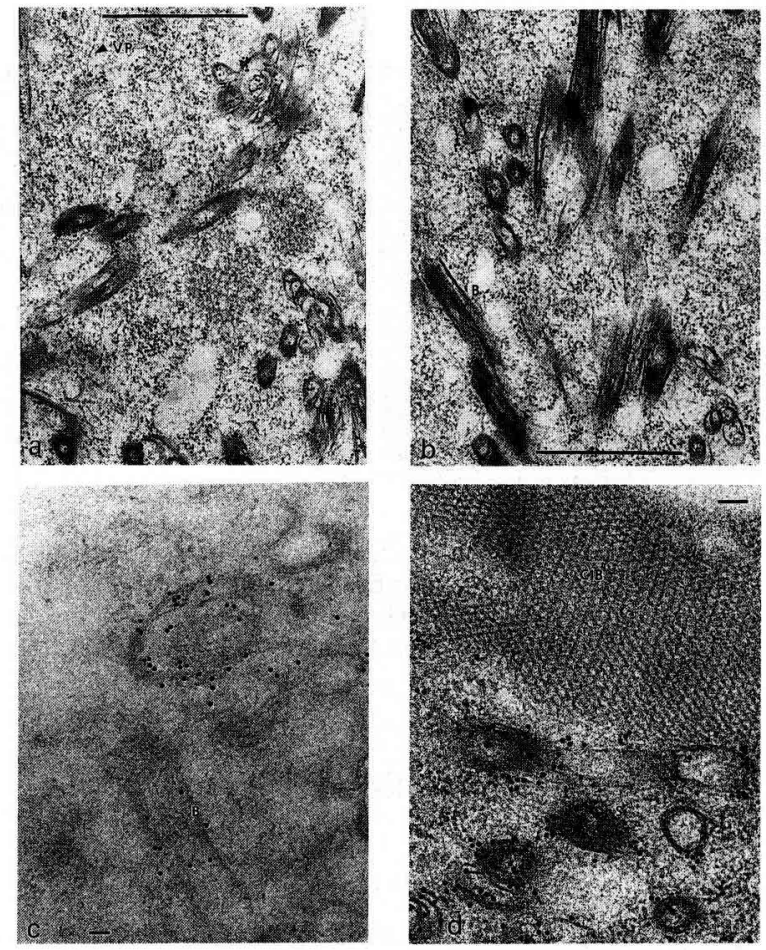

Fig 6. Infected leaf tissues treated with a mixture of the 2 types of immunoglobulin. a) Scrolls and virus particles specifically labelled. Bar: $1000 \mathrm{~nm}$; b) bundles and scrolls specifically labelled. Bar: $1000 \mathrm{~nm}$; c) bundles and scrolls specifically labelled; no lead staining of section. Bar: $100 \mathrm{~nm}$; d) scrolls specifically labelled. Crystalline inclusion body not specifically labelled. Bar: $100 \mathrm{~nm}$.

cles, pinwheel and crystalline inclusion bodies are serologically unrelated, and showed that the particles and the pinwheels can be selectively labelled by immunogold cytochemical staining.

\section{Possible function of PSbMV pinwheel inclusion bodies}

Pinwheel inclusion bodies associated with potyvirus infections have been implicated in virus cellto-cell movement because of their associations with plasmodesmata (Lawson and Hearon, 1971;

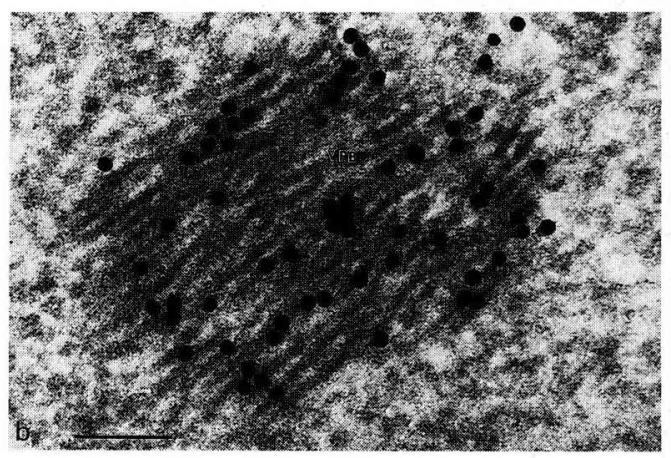

Fig 7. Infected plumule and cotyledon tissues treated with a mixture of the 2 types of immunogiobulin. Virus particle bundle (VPB) specifically labelled. a) Plumule section; b) cotyledon section. Bars: $100 \mathrm{~nm}$. 
Table I. Detection of PSbMV structures in leaf sections by 4 immunogold labelling procedures.

\begin{tabular}{|c|c|c|c|c|}
\hline & Procedure 1 & Procedure 2 & Procedure 3 & Procedure 4 \\
\hline $\begin{array}{l}\text { Sodium metaperiodate } \\
\text { incubation }\end{array}$ & $1 \mathrm{~h}, 22^{\circ} \mathrm{C}$ & $2 \mathrm{~h}, 30^{\circ} \mathrm{C}$ & $2 \mathrm{~h}, 30^{\circ} \mathrm{C}$ & $2 \mathrm{~h}, 30^{\circ} \mathrm{C}$ \\
\hline Antibody treatment * & $\begin{array}{l}4 \mu \mathrm{g} / \mathrm{ml} \\
15 \mathrm{~min} 22^{\circ} \mathrm{C}\end{array}$ & $\begin{array}{l}20 \mu \mathrm{g} / \mathrm{ml} \\
\text { overnight } 4^{\circ} \mathrm{C}\end{array}$ & $\begin{array}{l}8 \mu \mathrm{g} / \mathrm{ml} \\
\text { overnight } 4{ }^{\circ} \mathrm{C}\end{array}$ & $\begin{array}{l}4 \mu \mathrm{g} / \mathrm{ml} \\
\text { overnight } 4^{\circ} \mathrm{C}\end{array}$ \\
\hline Gold labelling & $15 \mathrm{~min}$ & $4 \mathrm{~h}$ & $1 \mathrm{~h}$ & $1 \mathrm{~h}$ \\
\hline $\begin{array}{l}\text { Labelling of } \\
\text { PSbMV stuctures }\end{array}$ & + & +++ & +++ & +++ \\
\hline $\begin{array}{l}\text { Non-specific labelling } \\
\text { on healthy sections }\end{array}$ & + & +++ & ++ & + \\
\hline
\end{tabular}

- Anti-PSbMV pinwheel inclusion body immunoglobulin diluted in 1\% BSA $0.02 \mathrm{M}$ Tris, $0.5 \mathrm{M} \mathrm{NaCl}$.

,,++++++ Intensity of gold labelling.

Weintraub et al, 1974; McMullen and Gardner, 1980 ), virus particles and viral coat proteins (Langenberg, 1986). With PSbMV, pinwheel inclusion bodies have been found associated with particles in negative staining (Inouye, 1971). Our results show that PSbMV particles are associated with some pinwheel inclusion bodies in vivo and it is possible that viral coat proteins are also present among pinwheel inclusion bodies. Possibly, as suggested for the pinwheel inclusion bodies of wheat streak mosaic virus and wheat spindle streak mosaic virus (Langenberg, 1986), PSbMV pinwheel inclusion bodies are involved in virus cell-to-cell spread.

The absence of specific labelling of PSBMV pinwheel inclusion bodies in cotyledon and plumule sections, and the fact that extracts made from similar tissues did not react with the antiserum used in above experiments (Wang, unpublished results) suggest that this type of structure might have lost its antigenicity in the dried infected embryo tissues. It is not known whether this loss of antigenicity of PSbMV pinwheel inclusion bodies in the dried embryo tissues would affect virus activation during germination of the infected embryos.

\section{Application of immunogold labelling in PSbMV research}

Immunogold labelling could be useful in further investigations of the possible involvement of PSbMV pinwheel inclusion bodies in virus movement. It could also be useful in studying the mechanisms of PSbMV seed transmission in pea plants. We are currently using immunogold labelling to investigate some crucial stages of PSbMV seed transmission, including the presence or absence of virus structures in ovules before fertilization, and virus invasion of embryos during their early stages of development.

\section{ACKNOWLEGMENTS}

We thank SEL Roberts for preparing the photomicrographs, $\mathrm{P}$ Gallois for the French translation and $\mathrm{AJ}$ Maule and M Harvey for helpful discussion. D Wang thanks the Horticultural Development Council for financial support during the course of this study.

\section{REFERENCES}

Alconero R, Provvidenti R, Gonsalves D (1986) Three pea seed-borne mosaic virus pathotypes from pea and lentil germplasm. Plant Dis 70, 783-786

Bendayan M, Zollinger M (1983) Ultrastructural localization of antigentic sites on osmium fixed tissues applying the protein A-gold technique. I Histochem Cytochem 31, 101-109

Christie RG, Edwardson JR (1977) Light and electron microscopy of plant virus inclusions. Fla Agric Exp Stn Monogr Ser 9, 150 pp

Dougherty WG, Carrington JC (1988) Expression and function of potyviral gene products. Annu Rev Phytopathol 26, 123-143

Edwardson JR (1974) Some properties of the potato virus Y-groups. Fla Agric Exp Stn Monogr Ser 5, $225 \mathrm{pp}$

Hampton RO, Phillips S, Knesek JE, Mink GI (1973) Ultrastructural cytology of pea leaves and roots in- 
fected by pea seed-borne mosaic virus. Arch Gesamte Virusforsch 42, 242-253

Hiebert E, Purcifull DE, Christie RG (1984) Purification and immunological analyses of plant viral inclusion bodies. Methods Virol 8, 225-278

Hollings M, Brunt AA (1981) Potyvirus group. In: CMV $A A B$ Descriptions of Plant Viruses. No 245

Inouye T (1967) A seed-borne mosaic virus of pea. Ann Phytopathol Soc Jpn 33, 38-42

Inouye T (1971) Cytoplasmic inclusions in plant cells infected with pea seed-borne mosaic virus. Nogaku Kenkyu 532, 189-196

Khetarpal RK, Maury Y (1987) Pea seed-borne mosaic virus; a review. Agronomie 7, 215-224

Laemmli UK (1970) Cleavage of structural proteins during the assembly of the head of bacteriophage T4. Nature (Lond) 227, 680-685

Langenberg WG (1986) Virus protein association with cylindrical inclusions of two viruses that infect wheat. J Gen Virol 67, 1161-1168

Lawson RH, Hearon SS (1971) The association of pinwheel inclusions with plasmodesmata. Virology 44 , 454-456

Lin NS, Langenberg WG (1983) Immunohistochemical localization of barley stripe mosaic virions in infected wheat cells. J Ultrastruc Res 84, 16-23

Miličic D, Plavsic B (1978) Contribution to the knowledge of pea seed-borne mosaic virus. Acta Bot Croat 37, 9-19
McMullen CR, Gardner WS (1980) Cytoplasmic inclusions induced by wheat streak mosaic virus. J Ultrastruct Res 72, 65-75

Mowat WP, Dawson S, Duncan GH (1989) Production of antiserum to a non-structural potyviral protein and its use to detect narcissus yellow stripe and other potyviruses. J Virol Methods 25, 199-210

Musil M (1966) Über das Vorkommen des Virus des Blattrollens der Erbse in der Slowakei (Vorlaufige Mitteilung). Biologia (Bratislava) 21, 133-138

Sherwood JL (1987) Comparison of a filter paper immunobinding assay, western blotting and an enzyme linked immunosorbent assay for the detection of wheat streak mosaic virus. J Phytopathol 118, 68-75

Stevenson WR, Hagedorn DJ (1969) A new seedborne virus of peas. Phytopathology 59, 1051-1052

Van Lent JWM, Verduin BJM (1985) Specific gold labelling bound to plant viruses in mixed suspensions. Neth J Plant Pathol 91, 205-213

Weintraub M, Ragetli HWT, Lo E (1974) Potato virus $Y$ particles in plasmodesmata of tobacco leaf cells. $J$ Ultrastruct Res 46, 131-148

White RF, Rybicki EP, Von Wechmar MB, Dekker JL, Antoniw JF (1987) Detection of PR 1-type proteins in Amaranthaceae, Chenopodiaceae, Graminae and Solanaceae by immunoelectroblotting. J Gen Virol 68, 2043-2048 